\title{
Web-Based Employee Recruitment Management System In PT. Tropic Abadi
}

\author{
Haryanto', Yudha Surya Putra ${ }^{2}$, Nabilla Natasyah ${ }^{3}$ \\ ${ }^{1,2}$ Lecturer at Raharja University, Faculty of Science and Technology \\ ${ }^{3}$ Raharja University Students, Faculty of Science and Technology, Department of Information \\ Systems Computer Accounting Concentration \\ Jl. Jenderal Sudirman No.40, RT.002/RW.006, Cikokol, Kec. Tangerang, Kota Tangerang, \\ Banten 15117 \\ e-mail: haryanto@raharia.info, yudha.surya@raharia.info, natasyah@raharia.info
}

\section{To cite this document:}

Haryanto, Putra, Y. S., \& Natasyah, N. (2020). Web-Based Employee Recruitment Management

System In PT. Tropic Abadi. Aptisi Transactions on Management (ATM), 4(2), 140-149.

DOI:

https://doi.org/10.33050/atm.v4i2.1250

\begin{abstract}
In a company, back and forth is largely determined by employees accompanied by increasing technology and science in all fields taking place so rapidly. Similarly, the HRD division at PT. Tropic Abadi when managing employee recruitment activities. Employee recruitment management system that runs at PT. Tropic Abadi is currently not running optimally, namely: through an online recruitment website as a medium to provide a bridge of communication regarding job vacancy information, where the process is less practical and adequate. So that management systems are needed in order to be able to do the process of managing employee recruitment to be faster, more precise, effective, and efficient. This research uses a research methodology that is structured system management through UML (Unified Modeling Language) and the final results achieved from writing this scientific journal are by implementing a web-based system for PT. Tropic Abadi in solving these problems, ranging from the speed of information provided and an easily managed database system.
\end{abstract}

Keywords: Information systems, UML, Recruitment.

\section{Introduction}

In the current era of disruption 5.0 advances in technology and science in all fields have taken place so rapidly, along with the increasing need for computer users to get relief in a variety of activities. Likewise, in a company, the progress and retreat are very certain from employees, because employees are the initial provision in their survival even though supported by sophisticated facilities and technology will not be meaningful if it is not supported by reliable and certainly high quality human resources.

The role of information technology in a company has changed significant. Information technology is not only expected to be a helper and simplify the company's operations, but has become part of the strategy in maintain employee performance[1]. Information Systems (SI) is a combination of technology information and activities of people using technology aimed at supporting operations and management. 
This company does not yet have a special system that is able to increase activities operational and reduce mistakes that exist in the company, namely in recruitment employees who are not right because the old system can not determine well which employees are eligible to work, then in absenteeism that is prone to occur errors due to the old system cannot separate employees take time off in attendance, besides it is prone to errors in payroll that is not according to performance due to the old system it's difficult to calculate the reduction and salary addition, then errors in managing employee data that take time off because the old system can not properly manage leave so that it occurs errors in attendance and payroll, in addition to employee data searching that has not been efficient because they have to look for it first in the employee information data of course it will take a longer time, then the data security issues of the employee are weak due to employee data that is easily manipulated, then problems in making reports on absenteeism and long salary because of the large amount of data that must be recapitulated, This makes it difficult for HRD to control employee performance.

Generally in every turn of the year, the company will carry out the process recruitment of new employees. In the implementation of employee, company recruitment still using a conventional selection system. With a system that is still conventional it allows the practice of collusion and nepotism. Prospective employees who have relatives in the company will have the opportunity higher accepted in the company he proposes, thus making other applicants those who have better potential will feel disadvantaged. This was triggered because the absence of a systematic and transparent selection system. To overcome these problems require a system that can support the decisions of parties company in order to get transparent and maximum results.

Recruitment is a two-way communication. Applicants want accurate information about what it's like working in an organization. Whereas organizations really want information accurate about the applicant if later the applicant becomes the employee. Recruitment is important for the organization because it has function to gather human resources into an organization. Recruitment has a strategic objective which focuses on the need to attract people high quality so that the company can get competitive advantage. Companies need to recruit people with the right ability to achieve organizational goals In order to create excellence competitive and higher organizational performance, The company must start by recruiting applicants possess the necessary knowledge and skills (also called the ability) to actually do the job that the company needs. Recruit people with competence and skills (abilities) which not suitable can affect company performance and then human resources in the company organization this, it can also slow down growth company. Conversely, recruitment is more effective if allows organizations to attract applicants with the right abilities, which meet organizational expectations. Before the organization can fill a vacancy job, the organization must look for people which not only qualifies for the position, but also wants the job.

PT. Tropic Abadi located at JI. KH Hasyim Ashari no. 8 Cipondoh - Tangerang is a company that has a focus on printing services. In informing job vacancies, the company is still running manually, namely: job vacancy information is carried out in print and by word of mouth as a communication medium in conveying information. Data management on the recruitment of new employees is still done manually and causes frequent loss of application data process and requires a long time, so the data presented is not accurate.

Prospective workers to be recruited can be taken from the internal organization and external organization. Recruitment of workers from within is usually done by organization / company that has long been running and has a good career system. Internal recruitment has advantages, including being inexpensive, internal promotion can maintain employee loyalty and dedication, and there is no need for an adaptation period that is too long, because it is used to the atmosphere. However, internal recruitment also means limiting the talent that is actually available to the organization and reducing the opportunity for new ideas to enter.

Based on the above problems, this research has the aim to design a system that is a web-based employee recruitment system. Therefore, from the previous process that is still manual in recruiting employees and causing frequent loss of the application data process and causing an increase in time, so that with this system in the process of recruiting employees will become computerized. It also can make it easier to process data and minimize the level of errors that exist. 
According to Rachmat Wibowo and A. Adibudin Alhalim (2018: 2)[2] One of the main keys in creating professional Human Resources (HR) is located in the process of Recruitment, Selection, Training and Development of prospective workers. Finding a professional and quality workforce is not easy. It is an obligation in an organization and companies must screen for new members or workers. For this reason, recruitment of workers is needed to screen applicants who wish apply. In organizations, this recruitment becomes one of the important processes in determining whether or not applicants are will apply to the organization.

After applications have been received, they must be screened to exclude individuals who do not meet the requirements based on job qualifications. In this process requires great attention especially for stem disqualification for reasons that are not right, so in this process required carefulness of the filter.

In addition, for the company expected with this system will greatly facilitate in select files applications that enter the company and reduce piles of files that don't used up. This system is considered very effective because it is designed to provide service in the form of information about job vacancies, hiring employees new, work test and information work placement through the network Internet.

\section{Research Method}

In this research the scientific work applies several research methods, namely Library Study

Method and System Design Method.

\section{a. Method of Literature Research}

In this literature study, it can be easier for researchers to find references and relevant information by finding more information towards research in accordance with the topic of the problem be the object of research, by reading books or existing literature so opinions from various experts on an issue. There are several literature studies that have been done conducted in previous studies regarding the management system of employee recruitment and other research related. Here are 6 (six) literature reviews including:

1. Research conducted by Rohmat Taufiq ${ }^{[3]}$ (2019) entitled "Analysis and Design of New Employee Acceptance Systems at Pt. Surya Toto Indonesia ", in 2019. In this system research was created using the analysis and design methods described in the form of UML used to facilitate the process of developing web-based information systems at PT. Surya Toto Indonesia.

2. This research was carried out by Septiani Nur Wulandari, Panji Surya, Rimadini Asri Ardi, Langgeng Listiyoko ${ }^{[4]}$ entitled "TUNG MUNG TANGERANG DECISION SUPPORT SYSTEM." This study describes the system that helps PT. Tung Mung Tangerang. The reason why PT. Tung Mung was chosen as the object of research because he did not yet have an online system for recruiting. Encouraging effective system improvements can determine the high level of applicants / job applicants. The development of corporate organizations will gradually force the formation of credibility in the computerized system so that high work performance is created.

3. This research was conducted by Muhammad Taufik Syastra ${ }^{[5]}$ entitled "DESIGN ANDROID BASED ERECRUITMENT SYSTEM" The design of the e-recruitment system has the aim to be able to accommodate the needs of the company concerned with the employee recruitment process. The place of this research is PT Mega Petro Synergy (PT. MPS). PT. MPS is a company that has a focus on construction engineering facilitators and heavy industry workers. The needs of PT. MPS is currently related to reducing advertising costs, real time data and errors due to the data entry process of applicants.

4. This research was conducted by Radiant Victor Imbar and Putri Irma K Bratawijaya entitled "RECRUITMENT INFORMATION SYSTEM AND APPLICATION ASSESSMENT APPLICATIONS USING PROFILE MATCHING"[6]. PT $X$ as one of the developing companies saw a need to build a recruitment information system. System that makes applicant data centralized. Making it easier to do the search and also facilitate the recruitment process.

5. This research was conducted by Diyan Agus Permana and Rizki Yudhi Dewantara entitled "ANALYSIS AND DESIGN OF WEB-BASED EMPLOYEE RECRUITMENT INFORMATION SYSTEM (Study at PT Sumber Abadi Bersama, Gondanglegi, Malang Regency) ${ }^{\text {"[7] }}$. The purpose of this research is to find out the description of the employee recruitment system that is applied at PT Sumber Abadi Bersama at this 
time, to analyze the employee recruitment system that is applied to develop the system in the form of a web-based employee recruitment information system design.

6. This research was conducted by Nurul Azizah, Sri Winiarti entitled "DECISION SUPPORT SYSTEM FOR EMPLOYEES PROSPECTIVE BY PROMETHEE METHOD OF PAMELLA GROUP YOGYAKARTA CASE STUDY"[8]. The subject in this study was the application of a decision support system that was used to assist the employee selection process that was in accordance with efforts to develop and perfect the school employee recruitment system needs to be done literature study as one of the application of research methods that will be done. Among them are: the criteria established by Pamella Group management. System design with a modified waterfall process model includes definitions of requirements needed by the user to be able to design the system for process modeling, data modeling and user interfaces.

From some literature studies that have been concluded that there are many studies that has been done regarding the employee recruitment system especially in terms of utilization, selection management system as well management. Where in this study focus on whether this system can said a container as management in job vacancies and employee selection management whether it can be useful or not online at the company.

\section{b. System Design Method}

After conducting research and analysis of the running system, then the next discussion of system design will be formed. There are a number of proposed procedures that aim to make improvements and improvements to the current employee recruitment system. In conducting analysis and system design that is recommended, in this study using the Visual Paradigm For UML 8.0 Entrepise Edition program. According to Leni Ancelina M. Kegou ${ }^{[8]}$ (2019), UML (Unified Modeling Language) is one of the tools that is very good object orientation in the world. This is because UML has a visual paradigm language that can provide the possibility for Developers to be able to make their oracles in standard form, easy to understand and fulfilled with effective procedures for sharing and bridging in communication design with others. Class Diagram of Information System Design Cover Letter describing the database design that will be used on the system. Employee Recruitment above is contained:

1. Class, a set of objects that share the same attributes and operations, namely: Registration, Vacancies, Jobs, and Applicants.

2. There are 4 Multiplicity, the relationship between one object with another object that has a value

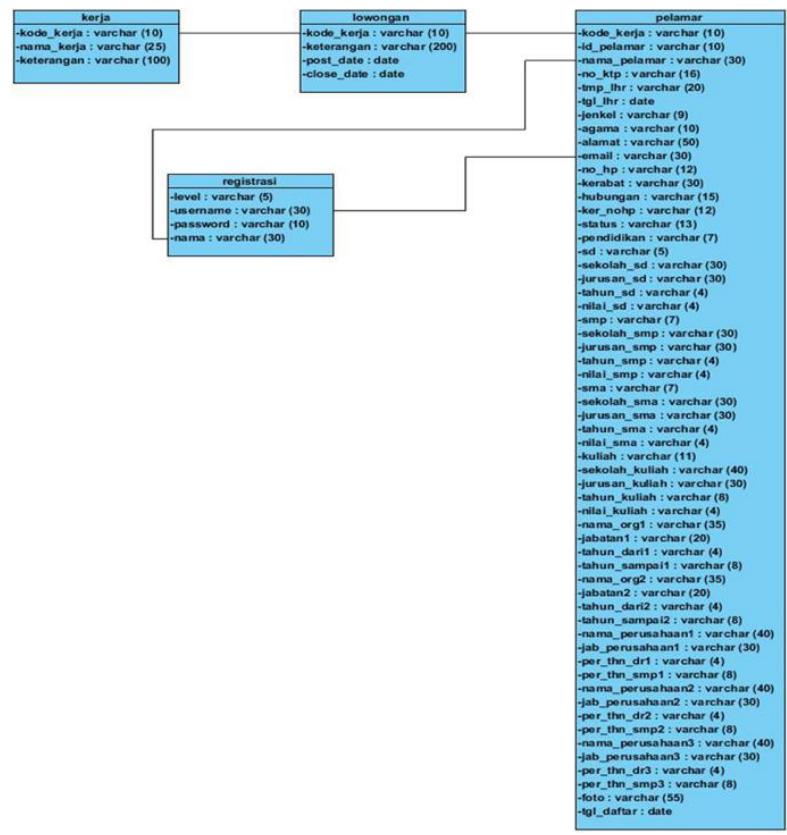

Figure 1. Class Diagram of Employee Recruitment Information System design 
Class diagram in a system is very supportive in doing class visualization. This is because the class is a description of the group of objects that have similarities in terms of relations and attributes (property). In addition class diagrams can provide global reviews on a system.

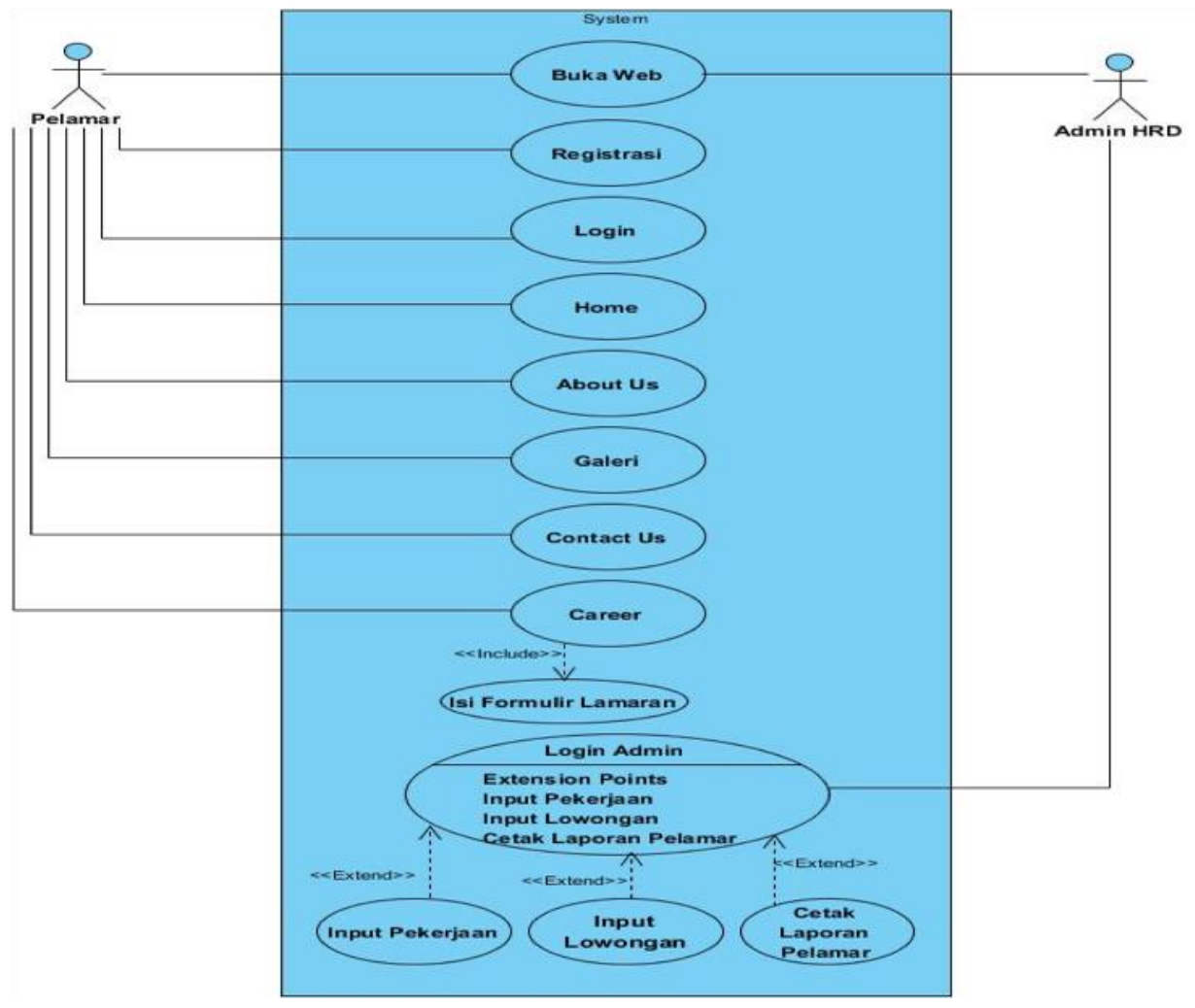

Figure 2. Use Case design of Employee Recruitment Information System

From the diagram above, there is 1 (one) system that covers all activities in the input process, 3 (three) actors working on the activities, namely the Governance Section, Secretariat, and Lurah, and 6 usecases that will be carried out by the actor, such as login, View Home, Create Mail, View Mail, Report, Logout. Based on Figure 2 the Use Case Diagram proposed above contains:

1. 1 The system that covers all the things that are running activities.

2. 2 Actors conducting activities, namely: Applicants, and HRD Admin.

3. 8 Use Cases conducted by these normal actors, including: Open the Web, Registration, Login, About Us, Home, Contact Us, Gallery, and Career.

4. 1 Include consists of: Fill in the Application Form.

5. 1 Extension Points that specify that through admin login include: Job Input, Job Vacancy Input, and Print Applicant Report.

\section{Results and Analysis}

In this research, we will explain the web-based employee recruitment system design. Making this system aims to provide job information, the company is computerized, so that the information is not manual such as: through print media and word of mouth as a communication medium in providing various kinds of job information. the authors designed a proposal system that can help and minimize the level of inaccuracy of the data obtained. The process of making this information system to facilitate HRD in recruiting employees. And the data generated will be more effective. After conducting research and analysis of the running system, then the next discussion of the system design to be built. There are a number of proposed procedures aimed at improving and perfecting the current employee recruitment system. To analyze and design the proposed system, this study uses the Visual Paradigm For UML 8.0 Entrepise Edition program.After seeing which system is running, the flow is designed proposal system and data flow diagram. Below is a display of the cover letter system: 


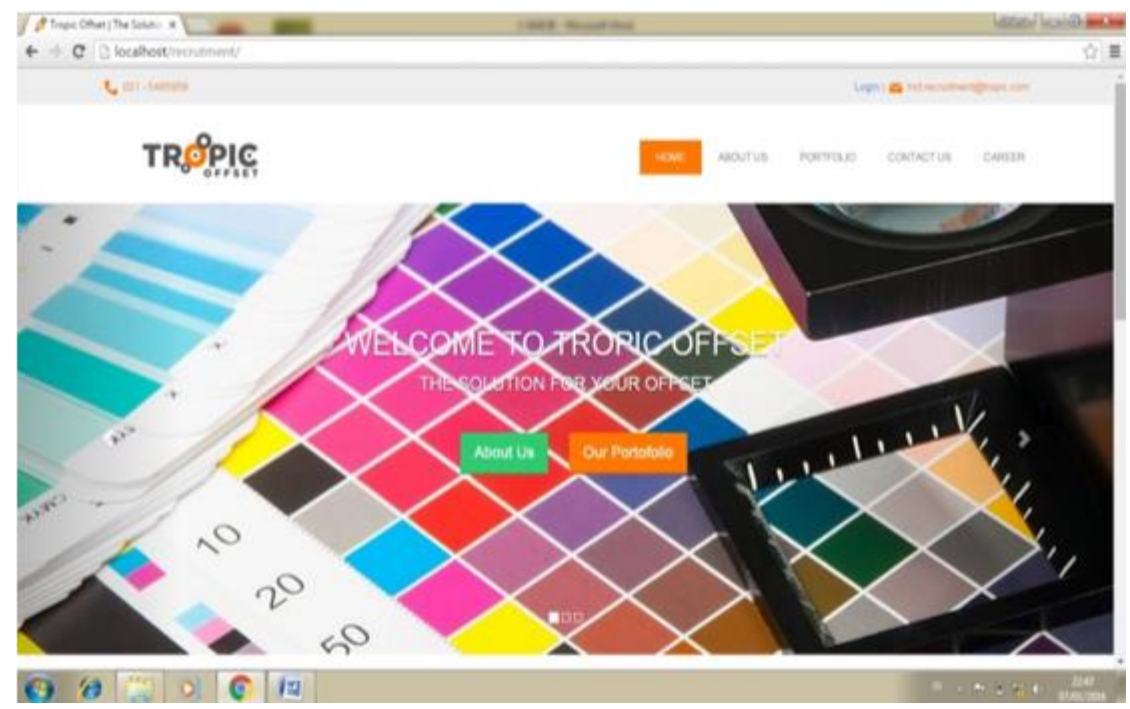

Figure 2. Main Menu

Figure 2 is the design of the main menu which has several noisy menus, such as: About Us, Contact Us, Gallery, Career. Where the main menu will prioritize the appearance of PT. Tropic Abadi and Job Vacancy Information.

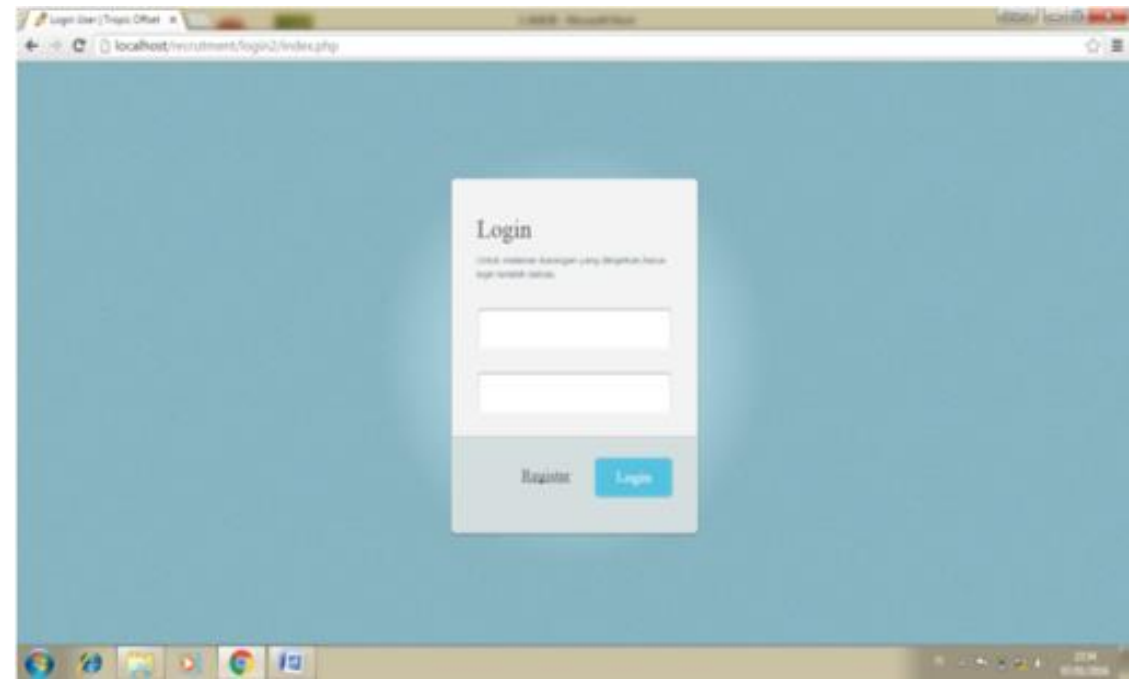

Figure 3. Login Menu

Figure 3 is a login design that can be accessed by admins and applicants who already have access rights to use the system. If applicants and admins want to enter the system, they must first enter a username (email) and password that they have as key to enter the system. However, if the user does not have an account, register first in order to access the system. 


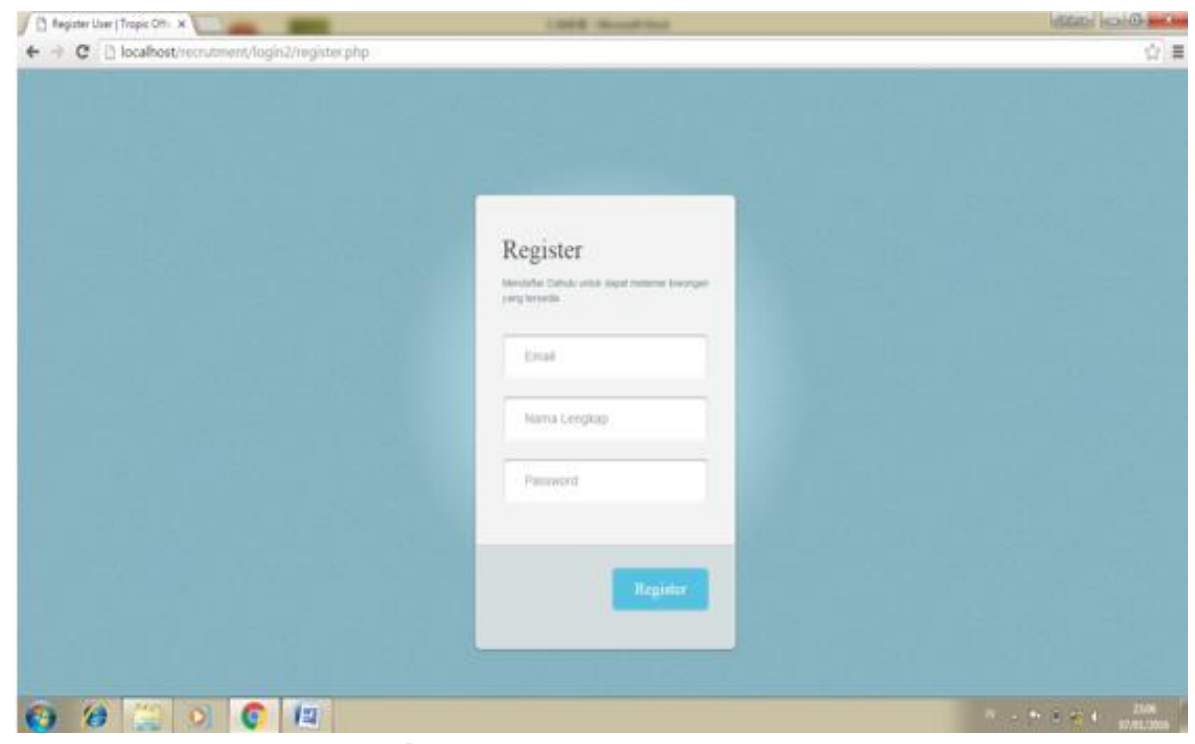

Figure 4. Registration Menu

Figure 4 is a registration design intended for applicants who do not yet have access rights. Applicants must enter their full name, password, and email address that are used as the username at login.

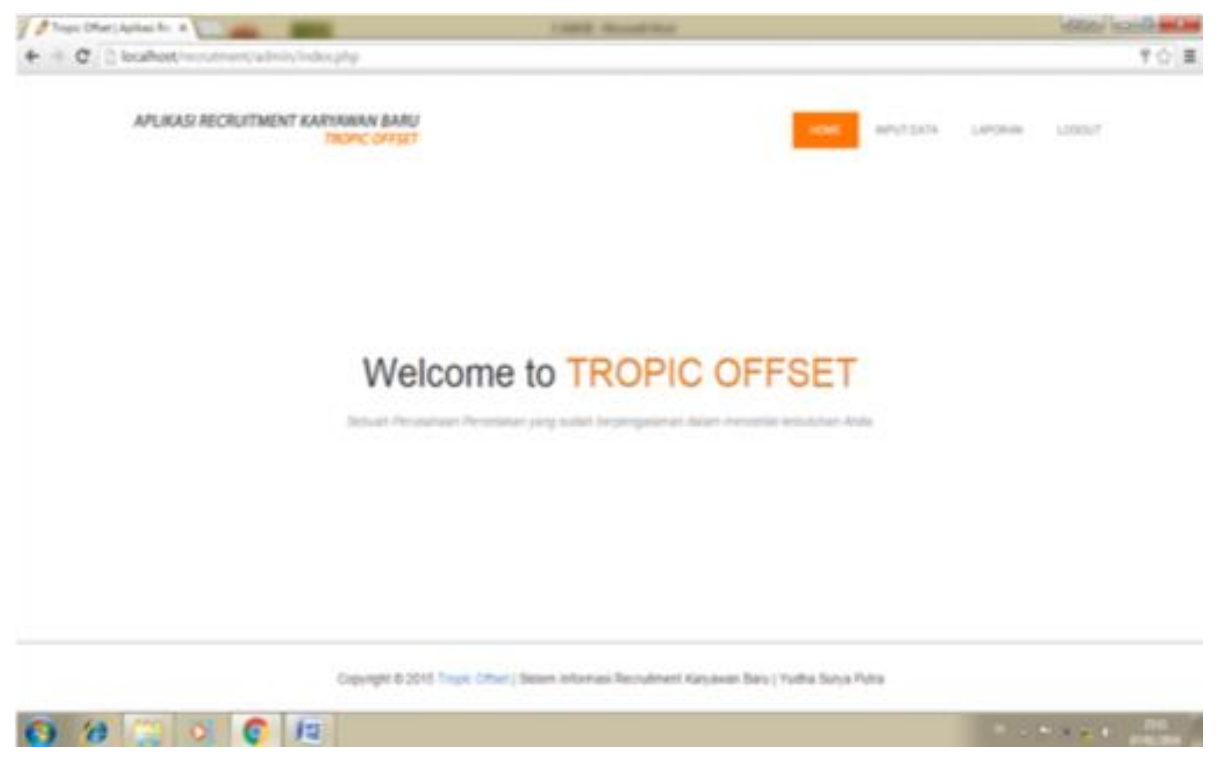

Figure 5. Admin Main Menu

Figure 5 is the design of the main menu for the admin which consists of: Data Input, Reports, and Logout. In the data input menu it functions as inputting jobs and vacancies, the report menu functions as a printer for reporting applicants and sees a list of incoming applications, and the logout menu functions as exiting the admin menu. 


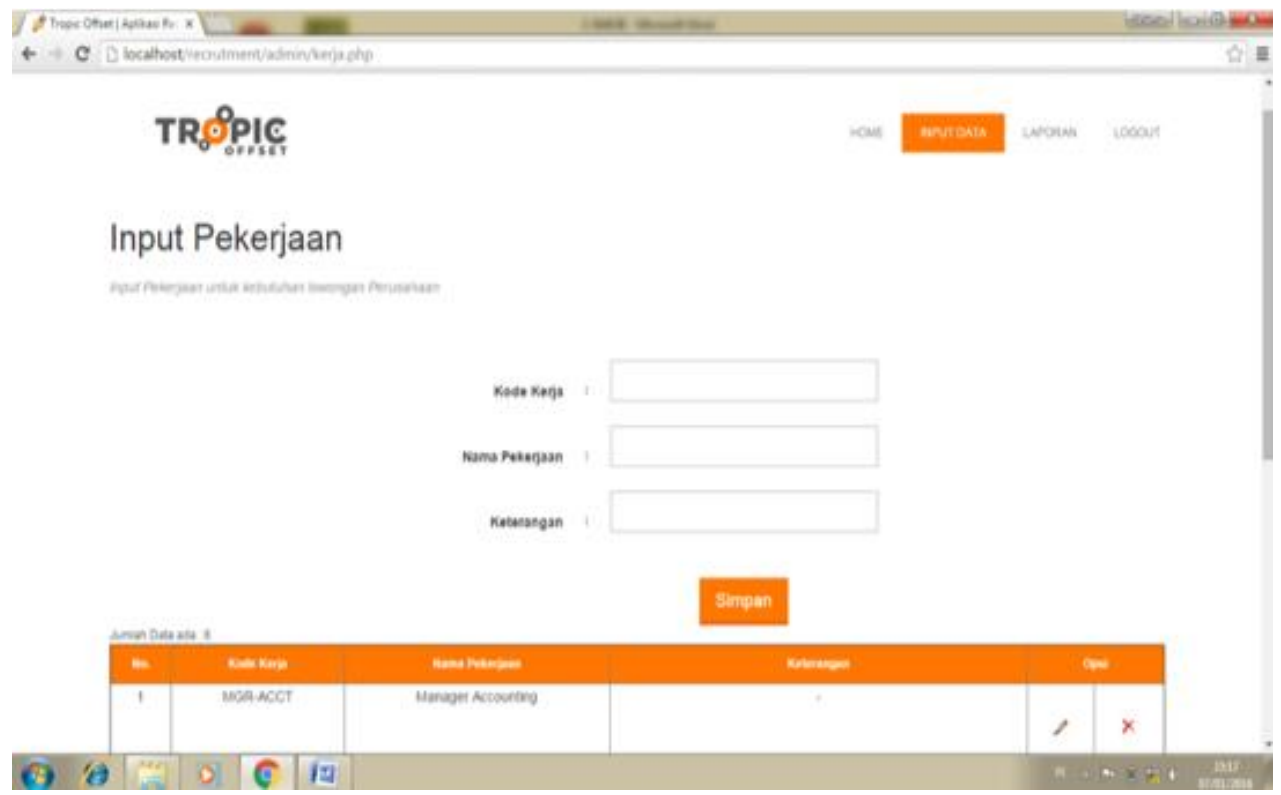

Figure 6. Job Input Menu

Figure 6 is a work input design, which is used to add, replace, and delete work codes for the HRD admin.

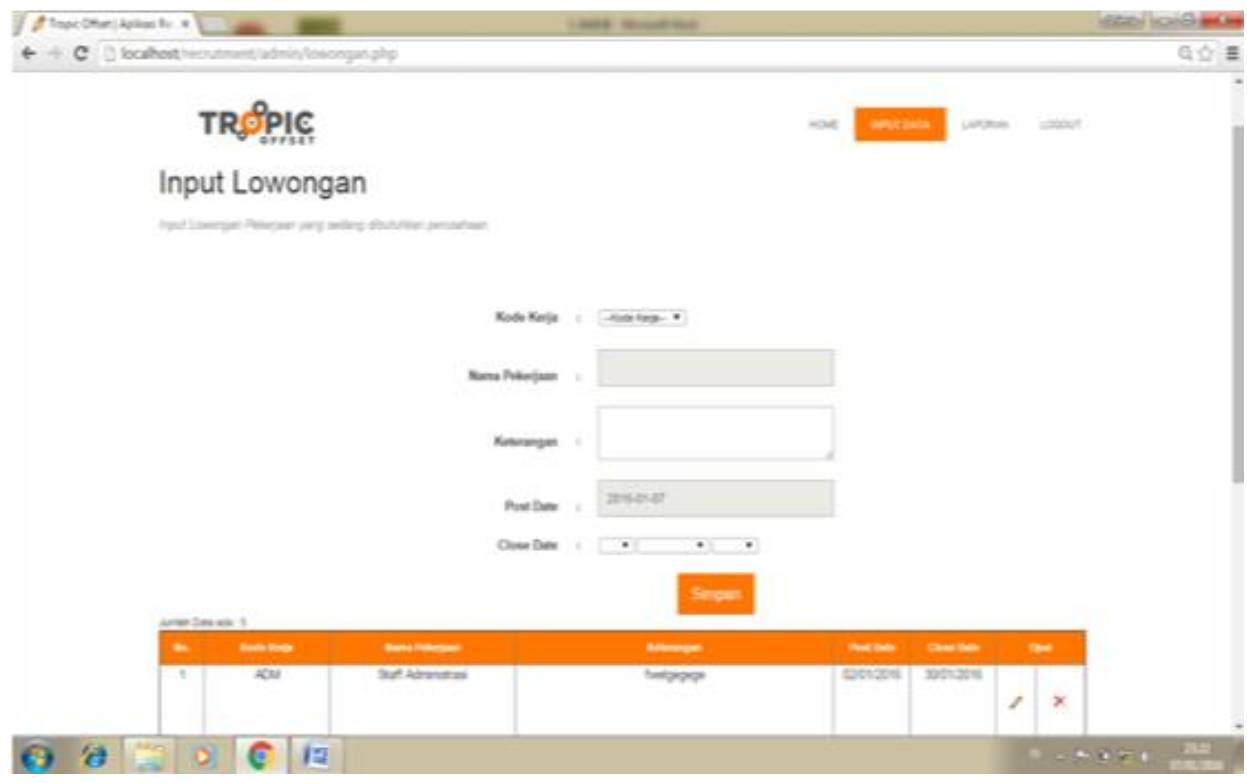

Figure 7. Job Input Menu

Figure 7 is a form of vacancy input design, which functions as an input, modifier, job eraser for HRD admin and will appear on the career menu seen by the applicant. 


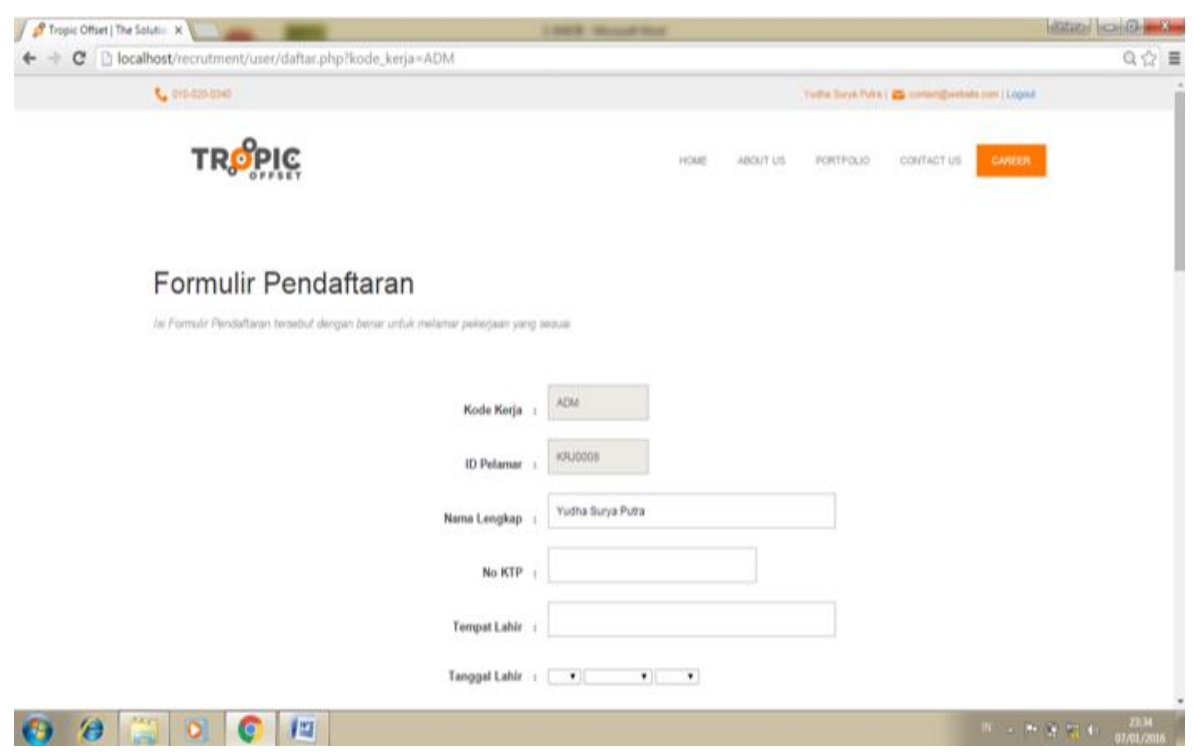

Figure 8. Menu Application Form

Figure 8 is a draft application form registration, which contains the identity of the applicant and so on.

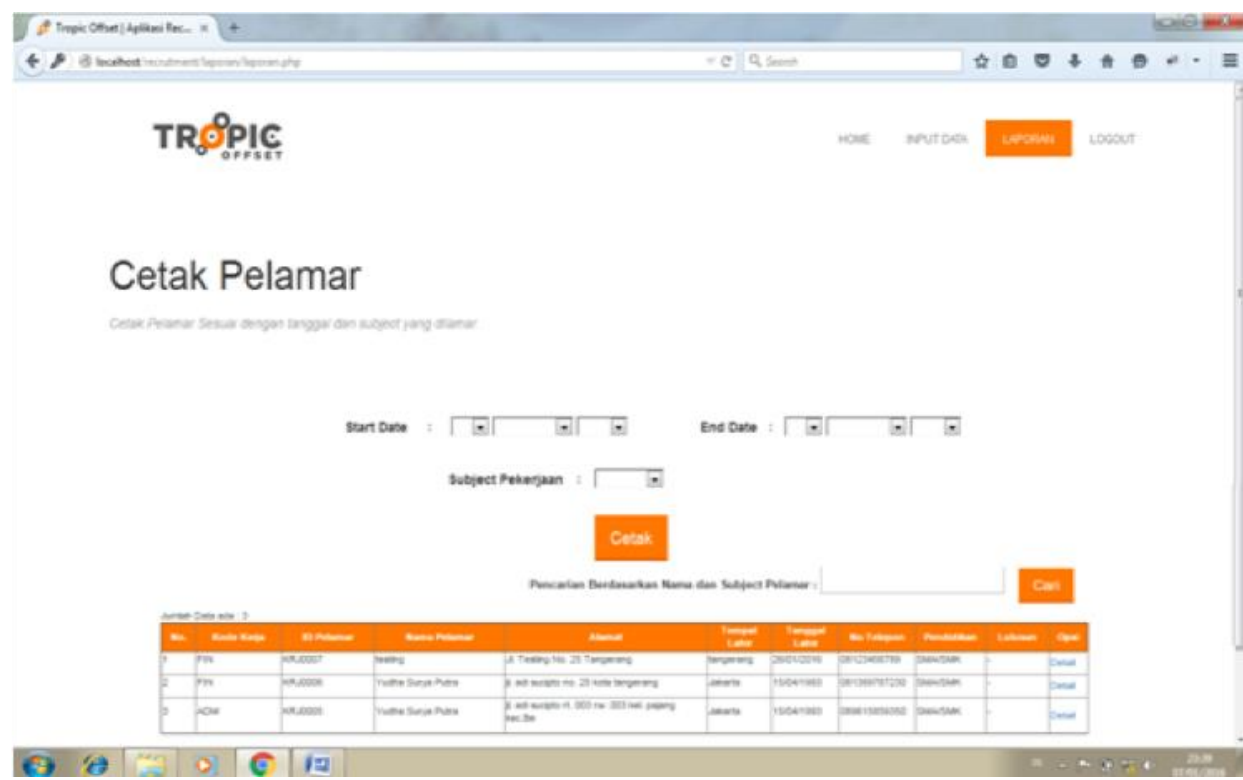

Figure 9. Report Menu

Figure 9 is a draft report. Admin can see the list of applicants who have entered and print applicants' reports.

\section{Conclusion}

Based on the results of research conducted by the author at PT. Tropic Abadi, then as the end of writing the Final Project Report (TA) provides the following conclusions:

1. The employee billing system currently in operation is still manual. Starting from the information on job openings and data collection of applicants, so frequent loss of applicant data occurs.

2. After the author analyzes the employee recruitment system that is running at PT. Tropoic Abadi, apparently the company does not yet have an online employee recruitment system.

3. Solutions in designing employee recruitment information systems using Unified Modeling Language $(\mathrm{UML})$, so that it can simplify the system design process. 


\section{References}

[1] Louis, A., Alfian, I., \& Hartati, E. Sistem Informasi Kepegawaian pada PT. Indo Beton Berbasis Desktop.

[2] AHDIANSYAH, F. (2019). PENGARUH PROSES REKRUTMEN, PROSES SELEKSI DAN KOMPETENSI KARYAWAN TERHADAP KINERJA KARYAWAN OUTSOURCING (Studi Kasus Divisi Commercial PT. Brilliant Ecommerce Berjaya, Periode Januari 2017-April 2017) (Doctoral dissertation, Universitas Mercu Buana).

[3] Taufiq, R., Maelani, N., \& Liesnaningsih, L. (2019). ANALISIS DAN DESAIN SISTEM PENERIMAAN KARYAWAN BARU PADA PT. SURYA TOTO INDONESIA. JIKA (Jurnal Informatika), 3(1).

[4] Listiyoko, L., Wulandari, S. N., Ardi, R. A., \& Surya, P. (2018). SISTEM PENDUKUNG KEPUTUSAN REKRUTMEN BERBASIS WEB DENGAN METODE WEIGHTED PRODUCT (WP) STUDI KASUS PT. TUNG MUNG TANGERANG. SEMNASTEKNOMEDIA ONLINE, 6(1), 2-8

[5] Syastra, M. T. (2017). RANCANG BANGUN SISTEM E-RECRUITMENT BERBASIS ANDROID. Jurnal Ipteks Terapan, 11(2), 116-127.

[6] Imbar, R. V., \& Bratawijaya, P. I. K. (2017). Sistem Informasi Rekrutmen dan Rekomendasi Penilaian Pelamar Menggunakan Profile Matching. Jurnal Informatika dan Sistem Informasi, 3(1), 10-22.

[7] Permana, D. A., \& Dewantara, R. Y. (2018). ANALISIS DAN PERANCANGAN SISTEM INFORMASI PEREKRUTAN KARYAWAN BERBASIS WEB (Studi pada PT Sumber Abadi Bersama, Gondanglegi, Kabupaten Malang. Jurnal Administrasi Bisnis, 56(1), 20-28.

[8] Azizah, N., \& Winiarti, S. (2014). Sistem Pendukung Keputusan Seleksi Calon Karyawan Dengan Metode Promethee Studi Kasus Pamella Group Yogyakarta. Jurnal Sarjana Teknik Informatika, 2(1), 264-278. 